\section{Beskjeden effekt av Tamiflu}

Nevraminidasehemmere har beskjeden effekt på influensasymptomer - sykdomsvarigheten blir redusert med omtrent én dag hos ellers friske. Det viser en Cochrane-oversikt som omfattet 20 randomiserte, placebokontrollerte studier (BMJ 2009; 339: b5106).

Oseltamivir har en sikker, men beskjeden effekt på laboratorieverifisert influensa og virker ikke på influensaliknende sykdom som ikke skyldes influensavirus. Stoffet skal derfor nesten utelukkende brukes under en epidemi, ifølge en kommentar i Ugeskrift for Læger (2010; 172: 24).

\section{Fysisk aktivitet etter tarmkreft er bra}

Det er kjent at fysisk aktive mennesker har lavere risiko for å få tykktarmskreft enn inaktive. Nå viser en ny studie at overlevende etter coloncancer lever lenger dersom de er fysisk aktive (Arch Intern Med 2009; 169: 2101-8).

Studien omfattet 668 menn med tidligere stadium 3-kolorektalcancer. Økt fysisk aktivitet var signifikant forbundet med lavere tarmkreftspesifikk mortalitet og totalmortalitet.

\section{Vekttap før fedmekirurgi er bra Ved multidisiplinær innsats kan de som er henvist til fedmekirurgi, oppnå et signifi- kant vekttap preoperativt. Størrelsen på vekttapet innvirker på komplikasjonsrisi- koen etter gastrisk bypass-operasjon - jo større vekttap, desto færre komplikasjoner (Arch Surg 2009; 144: 1150-5). \\ Data for 881 pasienter ble vurdert retro- spektivt. Alle gjennomgikk et seksmåne- ders program med medisinsk, psykologisk, kostholdsmessig og kirurgisk evaluering samt undervisning.}

mette.sagsveen@legeforeningen.no Tidsskriftet

Hejblum G Chalumeau-Lemoine L, loos V et Comparison of routine and on-demand prescrip tion of chest radiographs in mechanically ventilated adults: a multicentre, cluster-randomised two-period crossover study. Lancet 2009; 374 1687-93. overlege Ragnar Hotvedt ved Anestesiintensivavdeling eller i dødelighet, sier

den reduserte bruken av røntgen thorax ikke
førte til endring $\mathrm{i}$ intervensjoner hos pasientene, bortsett fra en endring av respirator-

\title{
God prognose ved kroniske korsryggssmerter
}

\section{Over en tredel av pasientene med kroniske, uspesifikke korsryggs- smerter er helt symptomfrie etter ni måneder.}

Kroniske korsryggssmerter utgjør et stort helseproblem. Mange prognostiske studier har svakheter som innebærer altfor pessimistiske estimater. I en australsk studie ble 406 personer med korsryggssmerter i over tre måneder fulgt $\mathrm{i}$ ett år for å identifisere prognostiske markører (1).

Den kumulative sannsynligheten for fullstendig restitusjon med henblikk på smerte, funksjonsevne og arbeidsstatus var $35 \%$ og $42 \%$ ved henholdsvis ni og 12 måneder. Tidligere sykmelding pga. korsryggssmerter, betydelig redusert funksjonsnivå eller høy smerteintensitet ved studiestart, lavt utdanningsnivå og frykt for vedvarende smerte var assosiert med forsinket restitusjon.

- Resultatene underbygger gjeldende behandlingsstrategi for denne pasientgruppen, sier professor Erik Bautz-Holter ved Nakke- og ryggpoliklinikken ved Oslo universitetssykehus, Ullevål. - Prognosen er god, derfor må pasientene bli trygge på at de kan opprettholde fysisk og sosial aktivitet så langt det er mulig, sier han.

- Resultatene kan faktisk tolkes enda mer positivt enn det forfatterne gjør. Etter ni måneder var tre firedeler enten symptom- frie eller hadde bare lette eller svært moderate plager, hvilket neppe er stort mer enn det man finner i normalbefolkningen. Bare ti personer var sykmeldt. Dette støtter en offensiv strategi for tilbakevending til arbeid - som gjøres best ved rask intervensjon med medisinsk avklaring, vektlegging av arbeid og/eller funksjonsfremmende tiltak, som trening, sier Bautz-Holter.

\section{Trine B. Haugen}

trine.b.haugen@hf.hio.no

Tidsskriftet

\section{Litteratur}

1. da Cunha Menezes Costa L, Maher CG, McAuley $\mathrm{JH}$ et al. Prognosis for patients with chronic low back pain: inception cohort study. BMJ 2009; 339 b3829. 